\title{
慢性腎臓病の重症化予防に向けた運動の役割
}

\author{
小㟝 恵生 ${ }^{1,2}$, 斎藤 知栄 ${ }^{3}$, 山縣 邦弘 $^{3}$, 前田 清司 $^{1}$
}

\section{Habitual exercise and prevention of chronic kidney disease}

\author{
Keisei Kosaki $^{1,2}$, Chie Saito ${ }^{3}$, Kunihiro Yamagata $^{3}$ and Seiji Maeda ${ }^{1}$ \\ 1筑波大学体育系，７305-8577 茨城県つくば市天王台1-1-1 (Faculty of Health and Sport Sciences, University of Tsukuba, \\ 1-1-1 Tennodai, Tsukuba, Ibaraki 305-8577, Japan) \\ ${ }^{2}$ 日本学術振興会, ₹ 102-8472 東京都千代田区敖町 5-3-1 (Japan Society for the Promotion of Science, 5-3-1 Kouzimachi, \\ Chiyoda-ku, Tokyo 102-8472, Japan) \\ 筑波大学医学医療系, ₹305-8575 茨城県つくば市天王台1-1-1 (Faculty of Medicine, University of Tsukuba, 1-1-1 Ten- \\ nodai, Tsukuba, Ibaraki 305-8575, Japan)
}

Received: September 20, 2018 / Accepted: October 5, 2018

Keywords : chronic kidney disease, physical inactivity, exercise

\section{はじめに}

持続的な腎臟の障害または機能低下と定義される慢性 腎臓病（CKD: chronic kidney disease）は，わが国の成 人 8 人に 1 人が罹患している「国民病」である ${ }^{1)}$. 加えて, その病態の進行は, ほとんどが不可逆的であり, 看過で きない生体負担と高額な医療費を必要とする人工透析の 導入につながるだけでなく心血管疾患の発症にも関与す る。したがって，高齢化の進むわが国に扔いて実用的な CKDの重症化予防策を確立し, 健康寿命を延伸させる ことは重要な社会的課題である。CKD発症・進行の危 険因子に目を向けてみると, 加齢や肥満などに加えて, 身体不活動もまた独立した危険因子の一つであることが 近年明らかにされている2).このことから最近, 身体不 活動の是正（定期的な運動実践）は, CKDの重症化予防 策を確立していく上で一部重要な役割を果たすと考えら れ始めている。 そこで本稿では，これまでの当該分野の 研究成果を中心にCKDの重症化予防に向けた定期的な 運動実践の役割について概説する。

\section{身体不活動とCKD}

身体活動指針で推奨されているような中高強度の身 体活動量が不足した状態である身体不活動は, 近年, “pandemic”な状態であるとの意見も出ている ${ }^{3)}$. CKD の発症に身体不活動が独立して関与することを考慮する と, 近年に打ける身体不活動の傾向がCKD患者の増加 に一部関与している可能性が考えられる。 その一方で, CKDを発症すると, その病態の重症化とともに身体活 動量や運動耐容能・身体機能が徐々に低下することも明 らかにされている ${ }^{4)}$ このことから CKD 患者の増加が身
体不活動者の増加に一部関与している可能性も考えられ る。したがって, 身体不活動, 運動耐容能・身体機能の 低下, CKDの発症・重症化は悪循環を形成しているこ とが示唆されている4).さらに，この悪循環はCKDを発 症していない状態に打いても一部観察されている, 我々 は, 健常な中高齢者を対象に, 身体活動量や運動耐容 能・身体機能と腎臓（特に近位尿細管）にかかる様々な ストレス度を反映するバイオマーカーである尿中 L 型脂 肪酸結合蛋白 (L-FABP: liver-type fatty acid-binding protein）の関連性を横断的に検討した，その結果，身体 活動量や運動耐容能・身体機能が低下している中高齢者 では，尿中L-FABP 值が有意に高值を示した ${ }^{5,6)}$ 。これら の結果は, 例え CKD を発症していない状態に抏いても, 身体活動量や運動耐容能・身体機能が低下している中高 齢者では, 腎臓にかかる様々なストレス度が大きい可能 性があることを示している，以上のことから，最近では， 前述した悪循環を断ち切って腎臟を保護する上で, 身体 不活動は修正可能で重要な介入標的になり得ると認識さ れ始めている ${ }^{4)}$.

\section{定期的な運動実践（運動療法）とCKD}

運動生理学の研究では, 運動中, 血流再配分の影響で 強度依存的に腎血流量が低下することが広く知られてい る。この運動中の腎血流量の低下は一過的な反応である にもかかわらず，過去には運動が腎臟病の増悪因子の一 つとして考えられ，腎臟病があれば絶対安静を強いられ てきた時代も存在した。しかし，現在においては，前述 の通り, 身体不活動が腎臟病の増悪因子の一つとして考 えられ，CKDの一次予防㧍よび二次予防を目的とした身 体不活動に対する介入として定期的な運動実践（運動療 
法）の意義が期待されている。実際に，2018年 6 月に日 本腎臓リハビリテーション学会から世界で初めて刊行さ れた腎臓リハビリテーションガイドラインに抏いても, 「保存期 CKD 患者に運動療法は推奨されるのか?」と いう clinical questionに対して, 運動療法は保存期 CKD 患者の運動耐容能や身体機能に関する生活の質 (QOL: quality of life）を改善・維持する可能性があることから, 「保存期 CKD 患者に対し, 年齢や身体機能を考慮しなが ら可能な範囲で運動療法を行うことを提案する.」とい う推奨文 (2C) が明記されている7)。しかしながら, 同 時に, 定期的な運動実践（または運動の習慣化）が腎臟 そのもの（腎機能や腎予後など）に及ぼす影響（運動療 法の腎保護効果）については, 確固たるエビデンスは現 在のところ存在しないことも明記されている。棟腎臟 学会発刊のエビデンスに基づく $\mathrm{CKD}$ 診療ガイドライン 2013に扔いても「運動がCKDの発症・進展に影響を与 えるか, 明らかではない」と述べられており ${ }^{8)}$ ， その後 に刊行されたエビデンスに基づく CKD 診療ガイドライ ン2018に抒いても「(肥満・メタボリックシンドローム を伴う）CKD患者に打ける運動療法の減量効果や最高 酸素摂取量の改善効果は明らかではあるが，腎機能など に対する効果はいまだ明らかではない」ことが述べられ ている ${ }^{1)}$. 以上のことをまとめると, 定期的な運動実践 (運動療法) は, CKDの重症化予防策の中で多岐にわたっ て重要な役割を果たす可能性は高いが，その立ち位置に ついては，まだ明確に定まっていないのが実情である。 したがって今後は, 運動の腎保護効果に関する質の高い 科学的なエビデンスを集積し, CKDの重症化予防策の 中に打ける定期的な運動実践（運動療法）の立ち位置を 明確にした上で, 食事療法や薬物療法などと組み合わせ ていく必要があると考えられる.

\section{おわりに}

近年の技術革新に伴う身体不活動の蔓延は世界的に大 きな問題となっている，実際に，世界保健機関（WHO： World Health Organization）は「健康のための身体活動 に関する国際勧告」を刊行し，その中で身体不活動が全 世界の死亡に対する 4 番目の危険因子であることを示し ている ${ }^{9)}$. このように, あらゆる疾患・病態の重要な危 険因子として身体不活動に注目が集まる中で, 最近では, CKD と身体不活動の関連性についても徐々に科学的な エビデンスが蓄積されてきており, 身体不活動の是正が
CKDの重症化予防に大きく貢献することはほぼ確実で あると考えられ始めている。しかしながら，CKDの重症 化予防に最適な運動の頻度, 様式, 時間, 強度などにつ いての検討は十分になされていない，加えて，定期的な 運動実践（または運動の習慣化）が腎保護的に作用する メカニズムについても数多くの不明点が残っている。 こ れらのことから，今後は，定期的な運動実践の腎保護効 果のメカニズムを探索する基礎的な検討とともに，実用 的な CKD 重症化予防策を確立するために, 運動プログ ラムの最適化を図る必要があると考えられる。

利益相反自己申告：申告すべきものはなし

\section{文献}

1）日本腎臟学会 (編). エビデンスに基づく $\mathrm{CKD}$ 診療ガイ ドライン 2018, 東京医学社, 53, 2018.

2) Hallan S, de Mutsert R, Carlsen S, Dekker FW, Aasarod K, Holmen J. Obesity, smoking, and physical inactivity as risk factors for CKD: are men more vulnerable? Am J Kidney Dis 47: 396-405, 2006.

3) Kohl HW, Craig CL, Lambert EV, Inoue S, Alkandari JR, Leetongin G, Kahlmeier S. The pandemic of physical inactivity: global action for public health. Lancet 380: 294-305, 2012.

4) Zelle DM, Klaassen G, van Adrichem E, Bakker SJ, Corpeleijn E, Navis G. Physical inactivity: a risk factor and target for intervention in renal care. Nat Rev Nephrol 13: 152-168, 2017.

5) Kosaki K, Kamijo-Ikemori A, Sugaya T, Tanahashi $K$, Sawano Y, Akazawa N, Ra SG, Kimura K, Shibagaki Y, Maeda S. Effect of habitual exercise on urinary livertype fatty acid-binding protein levels in middle-aged and older adults. Scand J Med Sci Sports 28: 152-160, 2018.

6) Kosaki K, Kamijo-Ikemori A, Sugaya T, Tanahashi K, Kumagai H, Sawano Y, Akazawa N, Ra SG, Kimura K, Shibagaki Y, Maeda S. Relationship between exercise capacity and urinary liver-type fatty acid-binding protein in middle-aged and older individuals. Clin Exp Nephrol 21: 810-817, 2017.

7）日本腎臟リハビリテーション学会（編）。腎臟リハビリ テーションガイドライン, 南江堂, 55-62, 2018.

8）日本腎臓学会 (編). エビデンスに基づく CKD 診療ガイ ドライン 2013, 東京医学社, 17, 2013.

9) World Health Organization. Global Recommendations on Physical Activity for Health, 2010. 